LANNA, NBL; SILVA, PNL; COLOMBARI, LF; CORREAA, CV; CARDOSO, AII. 2018. Residual effect of organic fertilization on radish production. Horticultura Brasileira 36: 047-053. DOI - http://dx.doi.org/10.1590/S0102-053620180108

\title{
Residual effect of organic fertilization on radish production
}

\section{Natália BL Lanna; Priscilla Nátaly L Silva; Lidiane F Colombari; Carla Veronica Corrêa; Antonio Ismael Inácio Cardoso}

Universidade Estadual Paulista(UNESP-FCA), Botucatu-SP, Brazil; nataliabllanna@gmail.com; priscilla_nataly@hotmail.com; colombarifl@ yahoo.com.br; cvcorrea1509@gmail.com; ismaeldh@fca.unesp.br

\begin{abstract}
This research aimed to evaluate the residual effect of doses of organic compost on the radish production, as well as its effect on soil chemical properties. Experiments were conducted in two areas ("low" and "high" soil fertility). Prior to this, these areas were first used to evaluate the influence of organic compost doses on endive production. After harvesting endive, radish seeds were sown into the same plots used for endive to evaluate the residual effect. The six treatments consisted of organic compost doses $(0,35,70,105,140$ and $\left.175 \mathrm{t} \mathrm{ha}^{-1}\right)$, evaluated in a complete block experimental design, with four replications. Vegetative characteristics of radish plants (shoot, root and total fresh and dry matter weight, plant height and root diameter) and soil characteristics (macronutrient content, $\mathrm{pH}$, $\mathrm{H}+\mathrm{Al}$, organic matter, sum of bases, cation exchange capacity and base saturation) in two dates (11 days after the endive transplant and at the end of the radish cycle) were evaluated. No significant difference was observed for all doses of organic compost in the "low" soil fertility area, obtaining only non-commercial roots (average fresh weight of 5.01 g per root). In the "high" soil fertility area, the higher the organic compost doses, the higher the values of most vegetatitve characteristics of radish plants and the chemical properties of the soil in both dates. For root fresh weight, the values ranged from 4.63 to $9.15 \mathrm{~g}$ in the control without organic compost and in the highest dose, respectively. In "high" soil fertility area, only K content in soil has not remained high for all organic compost doses, and the values ranged from 2.8 and $4.5 \mathrm{mmol} \mathrm{dm}^{-3}$, in control without organic compost and in the highest dose, respectively. The residual effect of organic compost was confirmed by the increasing on the radish production in initial "high"soil fertility area.
\end{abstract}

Keywords: Raphanus sativus, crop rotation, soil fertility, nutrient.

\section{RESUMO}

Efeito residual da adubação com composto orgânico na produção de rabanete

Objetivou-se com esta pesquisa avaliar o efeito residual da adubação com doses de composto orgânico na produção do rabanete, assim como o efeito nas características químicas do solo. Foram realizados experimentos em duas áreas distintas: um em solo com baixa fertilidade e outro em solo com alta fertilidade. Nestas áreas, inicialmente foi instalada uma pesquisa onde se estudou a influência de doses de composto orgânico na produção de chicória. Após a colheita desta, foi feita a semeadura do rabanete nas mesmas parcelas usadas na avaliação da chicória, visando avaliar o efeito residual da adubação feita para a chicória sobre o rabanete. O delineamento experimental utilizado foi de blocos ao acaso, com seis tratamentos e quatro repetições, sendo estes tratamentos as doses de composto orgânico $(0,35$, $70,105,140$ e $\left.175 \mathrm{tha}^{-1}\right)$. Foram avaliadas características vegetativas das plantas de rabanete (massa da matéria fresca e seca da parte aérea, da raiz e total; altura de plantas e diâmetro da raiz) e determinação dos teores de macronutrientes (potássio, fósforo, cálcio e magnésio), além do $\mathrm{pH}$, hidrogênio mais alumínio $(\mathrm{H}+\mathrm{Al})$, teor de matéria orgânica, soma de bases (SB), capacidade de troca catiônica (CTC) e saturação por bases (V\%) em duas datas (aos 11 dias após o transplante da chicória e ao final do ciclo do rabanete). Não foi observada diferença significativa para as doses de composto orgânico na área de "baixa" fertilidade, obtendo apenas raízes não comerciais (média da massa da matéria fresca de 5,01 g por raiz). Na área de "alta" fertilidade, quanto maior a dose de composto orgânico, maiores os valores da maioria das características vegetativas das plantas e das propriedades químicas do solo nas duas avaliações. Para a massa fresca de raiz, os valores variaram de 4,63 a 9,15 g na testemunha sem adubação e na maior dose de composto orgânico, respectivamente. Nesta área de "alta" fertilidade, apenas o teor de K no solo não se manteve elevado para todas as doses de composto orgânico, e os valores variaram de 2,8 e 4,5 $\mathrm{mmol}_{\mathrm{c}} \mathrm{dm}^{-3}$, na testemunha sem adubação e na maior dose de composto orgânico, respectivamente. Com isto, confirmou-se o efeito residual do composto orgânico pelo aumento na produção de rabanete na área de alta fertilidade do solo.

Palavras chave: Raphanus sativus, rotação de cultura, fertilidade do solo, nutrientes.

Received on July 21, 2016; accepted on June 19, 2017

$\mathrm{R}$ adish (Raphanus sativus) is a small-sized Brassicaceae, which is grown for its tuberous root and is a vegetable characterized by its short growing period (Yuan et al., 2014). It presents different forms (round, oval or elongated), sizes, colours (red, yellow, pink or white) and flavors (Filgueira,
2008).

Radish plants do not tolerate lower fertile soils (Basha \& El-Aila, 2015). Cecilio Filho et al. (1998) reported 
that radish is not demanding about soil type, but it needs to have a great deal of humus. Therefore, organic fertilizer must be incorporated into the soil to allow a good development of the root (Filgueira, 2008; Kumat et al., 2014). According to Trani \& Raij (1997), 30-50 $\mathrm{t} \mathrm{ha}^{-1}$ should be applied of wellaged cattle manure or organic compost, being necessary the largest dose for sandy soils.

Organic fertilizer provides some benefits to the soil, such as increasing water penetration and retention; improving the structure, aeration and porosity; increasing microbial life; enhancing the availability and uptake of nutrients in order to meet the crop demand. In tropical soils, the importance of organic fertilizers is even greater, because decomposition takes place more intensely (Villas Bôas et al., 2004).

In addition to many benefits that organic compost can provide to the soil, it also shows a slow nutrient release effect (Rodrigues et al., 2008; Yagioka et al., 2014), providing gradual nutrients release to the plant, which allows producers to save money on fertilizers.

Thus, we hypothesize that using organic fertilizer for a short duration crop it might allow planting, in sequence, another short duration crop, without the need for new fertilizers. Despite the importance of organic fertilizer and its benefits to the soil, there are few researches that related the doses of these fertilizers on radish production, as well as the residual effects of these on radish as a succeeding crop.

Therefore, present study was done to evaluate the residual effect of organic compost applied to a proceeding crop on radish as a succeeding crop and its effects on soil chemical properties.

\section{MATERIAL AND METHODS}

The experiment was conducted at São Manuel Experimental Farm, Botucatu School of Agronomy. The mean annual rainfall of São Manuel is $1445 \mathrm{~mm}$; and the mean annual temperature is $21^{\circ} \mathrm{C}$ (Cunha \& Martins, 2009). According to the Köppen classification, the climate in the region is mesothermic, Cwa, in other words, humid and subtropical, dry in the winter with a rainy season between November and April.

Two experiments were installed in two areas denominated "high" and "low" soil fertility areas. The soil of both areas is classified as typical dystrophic Red Latosol (Oxisoil) (Embrapa, 2013).

According to previous soil analysis, "low" fertility area presented: $\mathrm{pH}_{(\mathrm{CaCl})}=$ 5.2; organic matter $=9 \mathrm{~g} \mathrm{dm}^{-3} ; \mathrm{P}_{\text {resin }}=0$ $\mathrm{mg} \mathrm{dm}{ }^{-3} ; \mathrm{H}+\mathrm{Al}=17 \mathrm{mmol} \mathrm{dm}^{-3} ; \mathrm{K}=$ $1.4 \mathrm{mmol}_{\mathrm{c}} \mathrm{dm}^{-3} ; \mathrm{Ca}=16 \mathrm{mmol}_{\mathrm{c}} \mathrm{dm}^{-3}$; $\mathrm{Mg}=4 \mathrm{mmol}_{\mathrm{c}} \mathrm{dm}^{-3} ; \mathrm{SB}=22 \mathrm{mmol}_{\mathrm{c}} \mathrm{dm}^{-3}$; $\mathrm{CTC}=39 \mathrm{mmol}_{\mathrm{c}} \mathrm{dm}^{-3}$ and $\mathrm{V}=56 \%$. These values show zero phosphorus content, low potassium, high calcium, low magnesium and low $\mathrm{V} \%$ according to Raij et al. (1997). "High" fertility soil area presented: $\mathrm{pH}_{(\mathrm{CaCl} 2)}=5.8 ; \mathrm{OM}=12$ $\mathrm{g} \mathrm{dm}^{-3} ; \mathrm{P}_{\text {resin }}=99 \mathrm{mg} \mathrm{dm}^{-3} ; \mathrm{H}+\mathrm{Al}=13$ mmol dm ${ }^{-3} ; \mathrm{K}=2 \mathrm{mmol} \mathrm{dm}^{-3} ; \mathrm{Ca}=28$ $\mathrm{mmol}_{\mathrm{c}} \mathrm{dm}^{-3} ; \mathrm{Mg}=6 \mathrm{mmol}_{\mathrm{c}} \mathrm{dm}^{-3} ; \mathrm{SB}=$ $36 \mathrm{mmol} \mathrm{dm}^{-3}$; CTC $=49 \mathrm{mmol}_{\mathrm{c}} \mathrm{dm}^{-3}$ and $\mathrm{V}=74 \%$. According to Raij et al. (1997), phosphorus and calcium content can be considered high and potassium and magnesium content is medium in this area. In the "low" fertility area, liming was necessary two months before endive was planted (installed prior to radish), according to recommendation of Trani et al. (1997), to raise the base saturation to $70 \%$.

Both areas were previously used to study the influence of compost doses on endive (Cichorium endivia) production. After harvesting this crop, the radish was sown in the same plots of endive to evaluate the residual effect of compost applied to proceeding crop of endive on succeeding crop of radish.

The experimental design was randomized blocks, with six treatments and four replications. Initially, The average dose of organic compost of 70 $\mathrm{t} \mathrm{ha}^{-1}$, (Trani et al., 1997) was used for endive, the first crop cultivated in the areas. Based on the average, five doses were proposed, which varied from half to two and a half time of the recommended dose (i.e. 35; 70; 105; 140 and $175 \mathrm{tha}^{-1}$ on wet basis, with $31 \%$ humidity). We used a commercial compost, Provaso. In addition, a treatment without any fertilizer (control, dose $0 \mathrm{t} \mathrm{ha}^{-1}$ ) was evaluated, totalling six treatments. Each plot had $1.2 \mathrm{~m}^{2}$ containing 32 plants, but only 16 were considered useful.

Organic compost Provaso was analysed according to the methodology described by MAPA (2007), and presented the following chemical characteristics (given as a percentage in dry matter): $\mathrm{N}=0.5 ; \mathrm{P}_{2} \mathrm{O}_{5}=0.6 ; \mathrm{K}_{2} \mathrm{O}=$ $0.4 ; \mathrm{Ca}=1.4 ; \mathrm{Mg}=0.2 ; \mathrm{S}=0.2 ; \mathrm{U}-65^{\circ} \mathrm{C}=$ 31.0 ; organic matter $(\mathrm{OM}$-total $)=15.0$; $\mathrm{C}$-total $=8.0$. For every $100 \mathrm{tha}^{-1}$ of the compost, we applied 345, 414 and 276 $\mathrm{kg} \mathrm{ha}^{-1}$ of $\mathrm{N}, \mathrm{P}_{2} \mathrm{O}_{5}$ and $\mathrm{K}_{2} \mathrm{O}$, respectively. According to the chemical analysis of the organic compound, it is possible to compare this material (Provaso) with bovine manure, since it has similar chemical composition. However, each of the chemical compositions of both varies according to the locad it was produced. Organic compost was evenly distributed over the bed surface with a hoe and incorporated to a depth of 20 $\mathrm{cm}$. This incorporation was performed five days before the endive seedlings were transplanted (May 6, 2013). Apart from this fertilization at planting endive, that was cultivated before the radish, this first crop received top-dressing fertilization with castor bean cake (750 $\mathrm{kg} \mathrm{ha}^{-1}$ ), corresponding to $35 \mathrm{~kg} \mathrm{ha}^{-1}$ of $\mathrm{N}$, in all experimental plots, including the control $\left(0 \mathrm{t} \mathrm{ha}^{-1}\right)$.

Radish was sown on August 12, 2013 , i.e. five days after harvesting of endive (August 7, 2013), or 58 days after the organic compost was incorporated into the soil. Any new fertilization was made before sowing radish.

The hybrid Number 19 from Sakata was used. Sowing was held over four longitudinal rows in beds, spaced at 25 $\mathrm{cm}$. The spacing between plants after thinning (August 27, 2013) was $5 \mathrm{~cm}$.

A top-dressing was done 16 days after sowing (one day after thinning) with castor bean cake $\left(750 \mathrm{~kg} \mathrm{ha}^{-1}\right)$ in all plots, including control. In the control, fertilization with castor bean cake was done to receive the same treatment of all, except of the organic compost before endive planting. Therefore, control can be considered as zero dose $\left(0 \mathrm{t} \mathrm{ha}^{-1}\right)$ of organic compost in the regression analysis.

Weed was controlled by hoeing 
when necessary. In the absence of rainfall, irrigation was daily by using sprinkler system. There was no need to control pests and diseases.

Harvest was held on the September 23, 2013 (i.e. 42 days after sowing). To evaluate both areas of production, only 15 plants from two central rows of each plot were collected. The following characteristics were evaluated: plant height; shoot, root and total fresh matter (precision of $0.1 \mathrm{~g}$ ); shoot, root and total dry matter (by drying in an oven with forced air-circulation at $65^{\circ} \mathrm{C}$, until constant matter); and root diameter (by using a digital calliper).

In order to assess the effect of the treatments on the chemical characteristics of the soil, we collected three soil subsamples of each plot in each experimental area ("high" and "low" soil fertility) on the following days: July 1, 2013 (11 days after transplanting of endive) and September 27, 2013 (two days after harvesting of radish). These subsamples were mixed to form a single sample per plot and sent to the soil fertility laboratory to analyse, according to the methodology by Raij \& Quagio (1983). The following characteristics were evaluated: macronutrients content (potassium, phosphorus, calcium and magnesium), $\mathrm{pH}$, aluminium $(\mathrm{H}+\mathrm{Al})$, organic matter, sum of bases (SB), cation exchange capacity (CEC) and base saturation $(\mathrm{V} \%)$.

Data were subjected to analysis of variance and regression, to verify the effect of doses of organic compost in the evaluated characteristics. Analyses were performed in Sisvar 5.3 program (Ferreira, 2010).

\section{RESULTS AND DISCUSSION}

\section{Soil chemical properties}

Different doses of organic compost provided significant effect on the chemical properties of the soil in both collection dates. At 11 DAT (days after transplanting of the endive and at the end of the radish cycle), linear increases were obtained for organic matter (OM) in both areas (Figure 1A). For every 10 $\mathrm{t} \mathrm{ha}^{-1}$ of organic compost, OM content increased to 0.46 and $0.41 \mathrm{~g} \mathrm{dm}^{-3}$ in the "high" and "low" fertility areas, respectively. This result was lower than the one reported by Cardoso et al. (2011), who obtained $0.7 \mathrm{~g} \mathrm{dm}^{-3}$ for every $10 \mathrm{t} \mathrm{ha}^{-1}$ of compost within same soil condition.

Due to the increase of OM content in the soil, CEC also presented a linear increase of 0.1 and $1.4 \mathrm{mmol}_{\mathrm{c}} \mathrm{dm}^{-3}$ in the "high" and "low" fertility areas, respectively (Figure 1B), as well as SB (Figure 1C) that had an increase of 1.03 mmol $\mathrm{dm}^{-3}$ in "high" fertility area and $1.5 \mathrm{mmol} \mathrm{dm}^{-3}$ in "low" fertility area for every $10 \mathrm{t} \mathrm{ha}^{-1}$ of organic compost.

Regarding to macronutrients content, there was a linear increase in $\mathrm{Ca}, \mathrm{P}$ and $\mathrm{K}$ (Figure 1D, 1E and 1F) in both areas, while for $\mathrm{Mg}$ (Figure $1 \mathrm{G}$ ) only in the "low" fertility one. It shows that there was nutrient release from the organic compost, proportionally to its dose, as noted by other authors (Damatto Junior et al., 2006; Magro et al., 2010; Cardoso et al., 2011).

A linear effect was also observed on $\mathrm{pH}$ (Figure 1H) and V\% (Figure 1I) and reduction in $\mathrm{H}+\mathrm{Al}$ (Figure $1 \mathrm{~J}$ ) in "low" soil fertility area. According to Damatto Junior et al. (2006), adding organic matter to the soil may have the same effect of liming to neutralize soil acidification, because this acidity can be reduced by increasing $\mathrm{Ca}$ and/or $\mathrm{Mg}$ or possible adsorption of $\mathrm{H}+\mathrm{Al}$ on the organic matter surface. The same outcome has been reported by several authors, working with organic fertilizer in horticulture (Magro et al., 2010; Cardoso et al., 2011; Lima et al., 2016). In the "high" soil fertility area, there was no difference between the doses of organic compost for $\mathrm{pH}$ and $\mathrm{H}+\mathrm{Al}$, with averages of 6.03 and $13.42 \mathrm{mmol} \mathrm{dm}^{-3}$, respectively (Figures $1 \mathrm{H}$ and $1 \mathrm{~J}$ ).

At the end of the radish cycle, there was no difference between the compost doses for $\mathrm{pH}$ (Figure $2 \mathrm{H}$ ), $\mathrm{H}+\mathrm{Al}$ (Figure $2 \mathrm{~J}$ ), magnesium (Figure $2 \mathrm{G}$ ) and base saturation (Figure 2I) in the "low" soil fertility area. In the "high" soil fertility area, there was no difference between the doses of organic compost for $\mathrm{pH}$ (Figure 2H), phosphorus (Figure 2E) and $\mathrm{H}+\mathrm{Al}$ (Figure 2J). In this area, magnesium (Figure 2) and potassium (Figure 2F) showed quadratic effect.
For other soil properties, the effect was linear (Figure 2).

Vidigal et al. (1995) studied the residual effect of organic compost on lettuce production and observed an increase in phosphorus content at higher doses. Also on lettuce production, Souza et al. (2005) evaluated the residual effect of organic compost and observed a linear effect for phosphorus, potassium and magnesium, when they increased the dose. Also Cardoso et al. (2011) reported a linear increase in $\mathrm{Mg}$ content and $\mathrm{V} \%$ at the end of the lettuce seed production (more than 120 days) with organic compost.

Therefore, there was still residual effect of organic compost on most of the soil chemical properties after radish harvesting, i.e. 102 days after its incorporation, despite rainfall and sprinkler irrigation that favoured to leach some nutrients (especially $\mathrm{N}$ and $\mathrm{K}$ ) and nutrient absorption during endive and radish cycle.

At the end of the radish cycle, $\mathrm{pH}$ (5.8 and 6.0 for "low" and "high" soil fertility areas, respectively) (Figure $2 \mathrm{H}$ ) and V\% (71.8 for "low" fertility area and linear increase in "high" fertility area, ranging from 76.7 to 82.2) (Figure 2I) were both in proper range to radish production, according to Filgueira (2008). P remained high (Figure 2E), as well as $\mathrm{Ca}$ (Figure 2D) and $\mathrm{Mg}$ (Figure 2). Only K (Figure 2F) has not remained high for all doses of organic compost, according to the criteria of Raij et al. (1997), ranging from 1.7 (0 dose) to 4.3 mmol $\mathrm{dm}^{-3}$ (at $175 \mathrm{t} \mathrm{ha}^{-1}$ ) in "low" soil fertility area. In the "high" soil fertility area, $\mathrm{K}$ ranged from 2.8 ( 0 dose) to 4.5 $\mathrm{mmol}_{\mathrm{c}} \mathrm{dm}^{-3}$ (at $175 \mathrm{t} \mathrm{ha}^{-1}$ ).

\section{Doses of organic compost on radish production}

In the "low" soil fertility area, there was no significant difference between the organic compost doses for all traits, which resulted in very small roots, without commercial value (the average fresh matter of all treatments was 5.01 g per root). Due to initial "low" fertility of the soil, the nutrients provided by the organic compost were mostly used for the development of endives and 


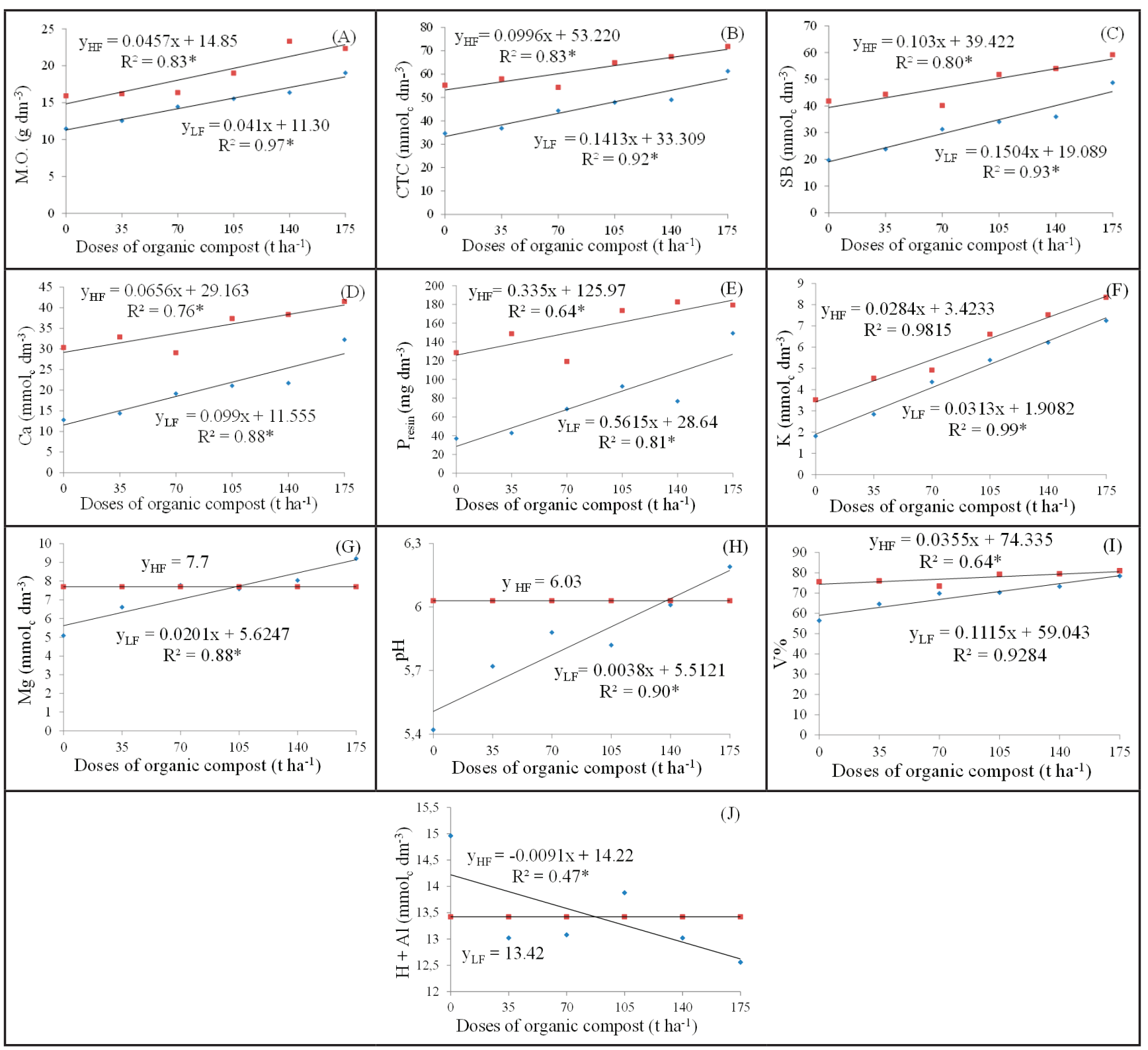

Figure 1. Chemical properties of the soil at 11 days after the endive transplant according to the dose of organic compost in the "low" ( $\mathrm{Y}_{\mathrm{LF}}$ ) and "high" $\left(\mathrm{Y}_{\mathrm{HF}}\right)$ soil fertility areas. São Manuel, UNESP, 2013.

weeds, being also lost by leaching; among others, leaving little nutrients for the radish. In "low" fertility area, K was probably the most limited growth nutrient to the plants, which values did not exceed $4.3 \mathrm{mmol}_{\mathrm{c}} \mathrm{dm}^{-3}$ at the end of the radish cycle (Figure $2 \mathrm{~F}$ ). In addition to $\mathrm{K}$, most chemical properties of the soil were lower in low fertility area within the two evaluations, explaining the little development of radish in this area. According to Filgueira (2008), radish does not tolerate low fertile soils and it requires high quantity of easily available nutrients in soil (Yuan et al., 2014).
In the "high" soil fertility area, there was a linear increase for shoot fresh matter (Figure 3A); root fresh matter (Figure 3B); total fresh matter (Figure 3C); shoot height (Figure 3D); root diameter (Figure 3E); shoot dry matter (Figure 3F); root dry matter (Figure $3 \mathrm{G}$ ) and total dry matter (Figure $3 \mathrm{H}$ ) by increasing the doses of organic compost. According to Kumar et al. (2014), Lima et al. (2016) and Kiran et al. (2016) organic fertilization improves growth and yield of radish.

For every $10 \mathrm{t} \mathrm{ha}^{-1}$ of organic compost added into the "high" soil fertility area, it increased $0.20 \mathrm{~g}$ of shoot fresh matter (Figure 3A); $0.25 \mathrm{~g}$ of root fresh matter (Figure 3B); $0.45 \mathrm{~g}$ of total fresh matter (Figure 3C); 0.23 $\mathrm{cm}$ in shoot height (Figure 3D); $0.37 \mathrm{~cm}$ in roots diameter (Figure 3E); $0.017 \mathrm{~g}$ in shoot dry matter (Figure 3F); 0.014 $\mathrm{g}$ in root dry matter (Figure $3 \mathrm{G}$ ); and $0.032 \mathrm{~g}$ of total dry matter (Figure $3 \mathrm{H}$ ). For the number of leaves, there was no significant difference between the doses of organic compost, with an average of 7.75 leaves per plant.

Root fresh matter ranged from 4.63 to $9.15 \mathrm{~g}$ in the "high" soil fertility area (Figure 3B), and the highest value is similar to the greater value (9.93 $\mathrm{g}$ ) 


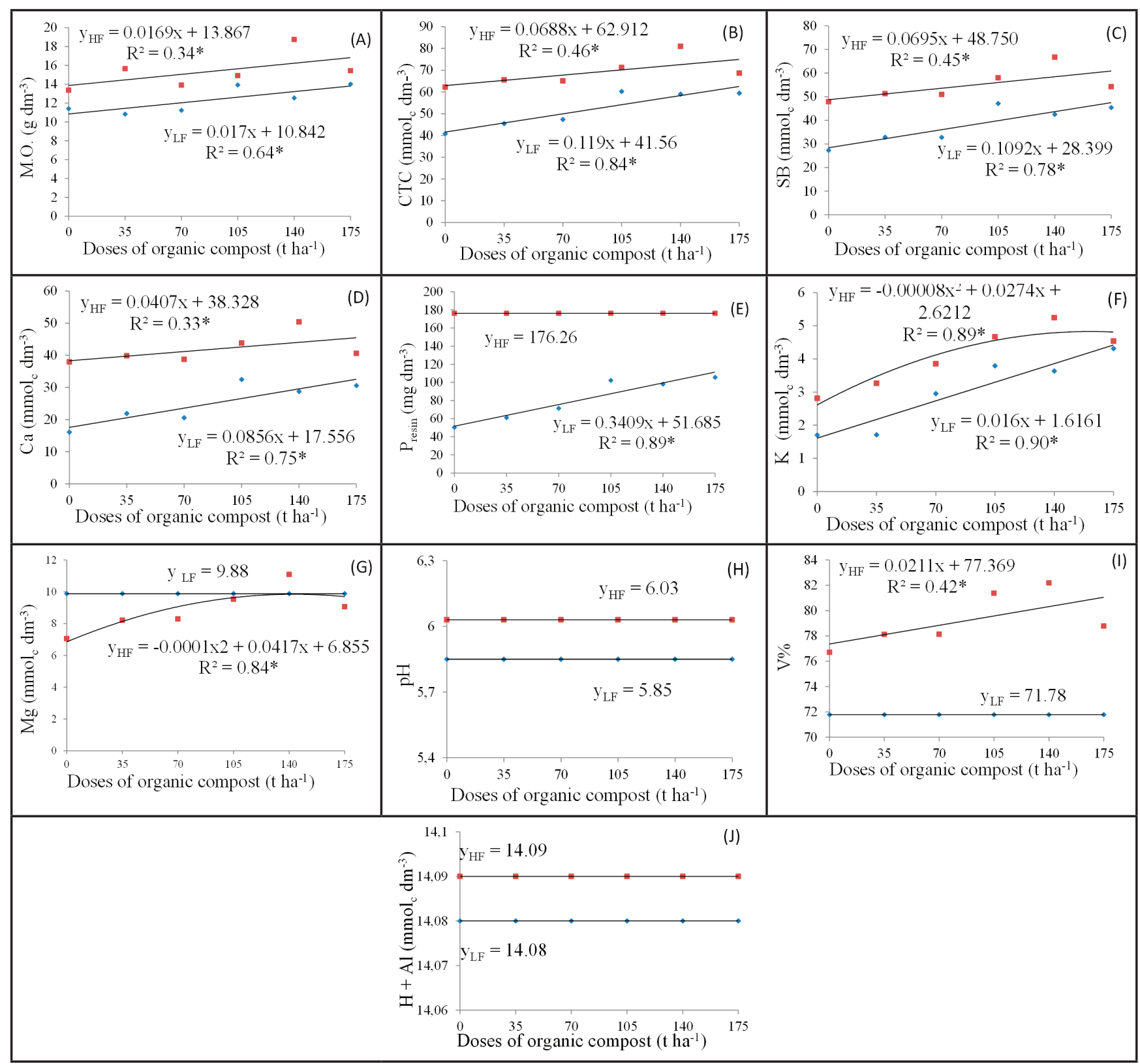

Figure 2. Chemical properties of the soil at the end of the radish cycle according to the dose of organic compost in the "low" $\left(\mathrm{Y}_{\mathrm{LF}}\right)$ and "high" $\left(\mathrm{Y}_{\mathrm{HF}}\right)$ soil fertility areas. São Manuel, UNESP, 2013.

obtained by Cardoso \& Hiraki (2001), who studied doses of calcium nitrate. Therefore, only the higher doses of organic compost in the "high" fertility area showed similar values of root fresh matter to the quoted authors. Reminding that there was no new fertilization at planting, but residual, therefore, it can be considered a positive outcome.

Besides the lack of fertilizer prior to sowing the radish seeds, the rainfall may also have contributed for nutrients loss. The total precipitation until 12 days after the endive seedlings transplant (DAET) was $72.6 \mathrm{~mm}$. This heavy rainfall may have caused nutrients leaching, which were found in the soil and released by the organic compost mineralization (especially K). During the radish experiments, precipitation was almost null at the beginning of the cycle. However, during the last week of the experiment precipitation was very intense $(69.5 \mathrm{~mm})$.

Organic matter decomposes quickly in moist tropical soils. When the organic matter content reduces excessively, the soil is harmed physically, chemically and biologically, and it can cause decreasing in production. Then, new organic fertilizer becomes necessary because low amount of organic matter begins to limit production (Malavolta et al., 2002). Therefore, especially in the "low" soil fertility area, residual effect of the compost was not enough, which shows that for a soil with initial nutrient deficiency, it needs to be treated with other organic fertilizers from different sources (green manure; adding organic matter for more than one cycle) to achieve the minimum level of nutrients in soil needed to supply all the plants demand to develop. In the traditional system, inorganic fertilizers are used 
in each cycle. However, in the organic system these fertilizers are not allowed.

In the "high" soil fertility area, most of the radish characteristics presented a linear increase, it is likely that organic fertilizer prior to the endive transplant was still taking effect, i.e., the radish was favored by the residual effect of fertilizer with organic compost without

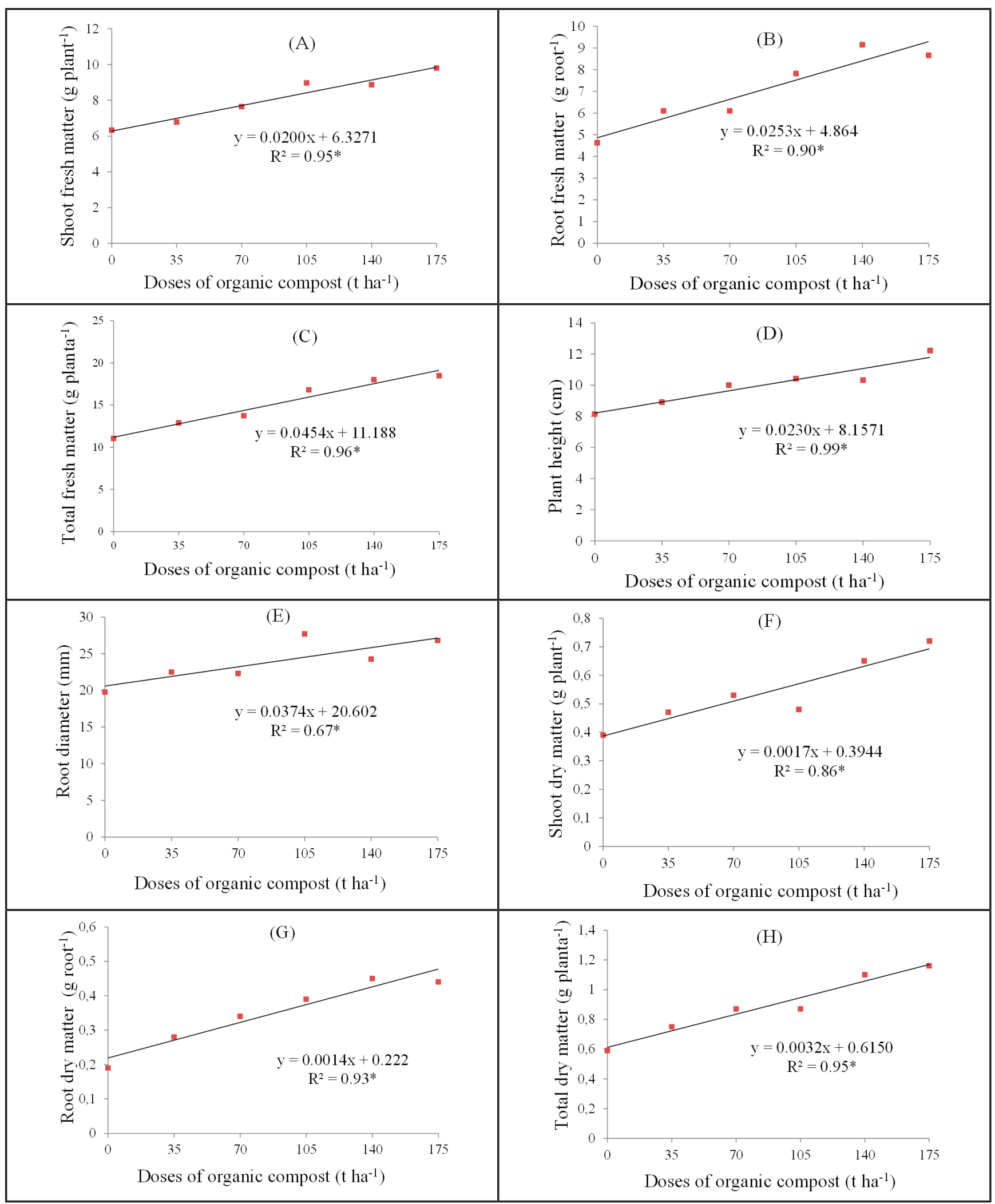

Figure 3. Shoot fresh matter (A), root fresh matter (B), total fresh matter (C), plant height (D), root diameter (E), shoot dry matter (F), root dry matter $(\mathrm{G})$ and total dry matter $(\mathrm{H})$ of radish plants according to the doses of organic compost in the "high" soil fertility area. São Manuel, UNESP, 2013. 
the need for re-fertilization. Linhares et al. (2010) studied doses of jitirana (5.4; 8.8; 12.2 and 15.6 tha $^{-1}$ on dry basis) and decomposition times $(0,10,20$ and 30 days before sowing), concluding that the residual effect of the higher dose (15.6 $\mathrm{t} \mathrm{ha}^{-1}$ ) at the longest period (30 days) was the one that provided the greatest number of leaves ( 7.5 leaves) and root diameter $(4.38 \mathrm{~cm})$ on radish. In this study, the time between the application of organic compost and sowing radish was 58 days. However, during this time, part of the nutrients was used by endive and weeds and some may have been leached, especially potassium, being the quickest nutrient released during the organic matter mineralization (Magro et al., 2010; Cardoso et al., 2011) and the rainfall were high $(72.6 \mathrm{~mm})$ during the endive cycle.

Based on the current study, the residual effect of organic fertilizer is confirmed, improving the chemical properties of soil and production of radish in the "high" soil fertility area.

\section{REFERENCES}

BASHA, DMRA; EL-AILA, HI. 2015. Response of foliar spraying with amino acids and integrated use of nitrogen fertilizer on radish (Raphanus sativus) plant. International Journal of ChemTech Research 8: 135-140.

CARDOSO, AII; FERREIRA, KP; VIEIRA JÚNIOR, RM; ALCARDE, C. 2011. Alterações em propriedades do solo adubado com doses de composto orgânico e efeito na qualidade das sementes de alface. Horticultura Brasileira 29: 594-599.

CARDOSO, AII; HIRAKI, H. 2001. Avaliação de doses e épocas de aplicação de nitrato de cálcio em cobertura na cultura do rabanete. Horticultura Brasileira 19: 196-199.
CECÍLIO FILHO, AB; FAQUIN, V; FURTINI NETO, AE; SOUZA, RJ. 1998. Deficiência nutricional e seu efeito na produção de rabanete. Cientifica 26: 231-241.

CUNHA, AR; MARTINS, D. 2009. Classificação climática para os municípios de Botucatu e São Manuel, SP. Irriga 14: 1-11.

DAMATTO JÚNIOR, ER; VILLAS BÔAS, RL; LEONEL, S; FERNANDES, DM. 2006. Alterações em propriedades de solo adubado com doses de composto orgânico sob cultivo de banananeira. Revista Brasileira de Fruticultura 28: 546-549.

EMBRAPA. 2013. Sistema brasileiro de classificação dos solos. 20 de novembro.

FERREIRA, DF. 2010. Sisvar versão 5.3. Lavras: Departamento de Ciências Exatas-UFLA.

FILGUEIRA, FAR. 2008. Novo manual de olericultura: agrotecnologia moderna na produção e comercialização de hortaliças. Viçosa: UFV. 421p.

KIRAN, M; JILANI, MS; WASEEM, K; SOHAIL, M. 2016. Effect of organic manures and inorganic fertilizers on growth and yield of radish (Raphanus sativus). Pakistan Journal of Agricultural Research 29: 363-372.

KUMAR, S; MAJI, S; KUMAR, S; SINGH, HD. 2014. Efficacy of organic manures on growth and yield of radish. International Journal of Plant Science 9: 57-60.

LIMA, VN; SILVA, RVTO; NUNES, P; SILVA, PH; MORANT, K; ANDRADE, RFS; NASCIMENTO, AE; TAKAKI, GMC; MESSIAS, AS. 2016. Green and Sustainable Chemistry 6: 1-10.

LINHARES, PCF; PEREIRA, MFS; OLIVEIRA, BS; HENRIQUES, GPSA; MARACAJÁ, PB. 2010. Produtividade de rabanete em sistema orgânico de produção. Revista Verde de Agroecologia 5.

MAGRO, FO; SALATA, AC; CARDOSO, AII; FERNANDES, DM. 2010. Composto orgânico na produção e qualidade de sementes de brócolis. Ciência e Agrotecnologia 34: 596-602.

MALAVOLTA, E; GOMES, FP; ALCARDE, JC. 2002. Adubos e adubações. São Paulo: Nobel.

MAPA. 2007. Manual de métodos analíticos oficiais para fertilizantes minerais, orgânicos, organo-minerais e corretivos. Instrução Normativa 28 de 27/07/2007.
RAIJ, B; CANTARELLA, H; QUAGGIO, JA; FURLANI, AMC. 1997. Recomendações de adubação e calagem para o Estado de São Paulo. Campinas: Instituto Agronômico e Fundação IAC.

RAIJ, B; QUAGGIO, JA. 1983. Métodos de análises de solo para fins de fertilidade. Campinas: Instituto Agronômico (Boletim Técnico, 81).

RODRIGUES, GO; TORRES, SB; LINHARES, PCF; FREITAS, RS; MARACAJÁ, PB. 2008. Quantidade de esterco bovino no desempenho agronômico da rúcula (Eruca sativa L.), cultivar Cultivada. Revista Caatinga 21: 162-168.

SOUZA, PA; NEGREIROS, MZ; MENEZES, JB; BEZERRA, NF; SOUZA, GLFM; CARNEIRO, CR; QUEIROGA, RCF. 2005. Características químicas de alface cultivada sob efeito residual da adubação com composto orgânico. Horticultura Brasileira 23: 754-757.

TRANI, PE; RAIJ, B. 1997. Hortaliças. In: RAIJ, B; CANTARELla, H; QUAGGIO, JÁ; FURLANI, AMC (eds). Recomendações de adubação e calagem para o Estado de São Paulo. Campinas: Instituto Agronômico \& Fundação IAC. p. 285.

VIDIGAL, SM; RIBEIRO, AC; CASALI, VWD; FONTES, LEF. 1995. Resposta da alface (Lactuca sativa L.) ao efeito residual da adubação orgânica. I Ensaio de campo. Revista Ceres 17: 80-88.

VILLAS BÔAS, RL; PASSOS, JC; FERNANDES, M; BÜLL, LT; CEZAR, VRS; GOTO, R. 2004. Efeito de doses e tipos de compostos orgânicos na produção de alface em dois solos sob ambiente protegido. Horticultura Brasileira 22: 28-34.

YAGIOKA, A; KOMATSUZAKI, M; KANEKO, N. 2014. The effect of minimum tillage with weed cover mulching on organic daikon (Raphanus sativus var. longipinnatus) yield and quality and on soil carbon and nitrogen dynamics. Biological Agriculture \& Horticulture 30: 228-242.

YUAN, WL; YUAN, SY; WANG, QF; GAN, CX; LIU, YH; MEI, SY. 2014. Effect of different amount of $\mathrm{N}$-fertilizers on growth, root yield and nitrate content of white radishes in southern China. Journal of Food, Agriculture and Environment 12: 302-304 